\title{
Dichloromethane utilized by an anaerobic mixed culture: acetogenesis and methanogenesis
}

\author{
Susanna A. Stromeyer, ${ }^{1}$ Wolfgang Winkelbauer, ${ }^{2}$ Herbert Kohler, ${ }^{2}$ Alasdair M. Cook ${ }^{1} \&$ \\ Thomas Leisinger ${ }^{1, *}$ \\ ${ }^{1}$ Microbiology Institute, Swiss Federal Institute of Technology, ETH-Zentrum, CH-8092 Zürich, \\ Switzerland; ${ }^{2}$ Mercedes-Benz AG, D-7000 Stuttgart, Germany (* requests for offprints)
}

Key words: anaerobic dehalogenation of dichloromethane; dichloromethane, anaerobic degradation; anaerobic fixed-bed reactor, dichloromethane; C-1 metabolism

\begin{abstract}
Dichloromethane $(8.9 \mathrm{mg} / \mathrm{l})$ was eliminated from industrially polluted, anaerobic groundwater in a fixed-bed reactor $\left(43 \mathrm{~m}^{3}\right)$ which was packed with activated charcoal and operated continuously for over three years. The elimination of dichloromethane over this period was some ten-fold in excess of the sorptive capacity of the charcoal, and the elimination $(3.7 \mathrm{mg} / \mathrm{h} \cdot[\mathrm{kg}$ of charcoal]: residence time, $49 \mathrm{~h})$ was tentatively attributed to dehalogenative microorganisms immobilized on the charcoal. Anaerobic enrichment cultures, with dichloromethane as the sole added source of carbon and energy, were inoculated with material from the reactor. Reproducibly complete substrate disappearance in subcultures was observed when traces of groundwater $(1 \%)$ or yeast extract $(0.01 \%)$ were supplied. Fed-batch experiments under an atmosphere of $\mathrm{CO}_{2}$ plus $\mathrm{N}_{2}$ led to the conversion in 11 days of $11 \mathrm{mM}$ dichloromethane to $3 \mathrm{mM}$ acetate and $2 \mathrm{mM}$ methane, with a growth yield of $0.4 \mathrm{~g}$ of protein $/ \mathrm{mol}$ of dichloromethane; insignificant amounts $(<1 \mu \mathrm{M})$ of chloromethane accumulated. Methanogenesis could be inhibited by $50 \mathrm{mM} 2$-bromoethane sulfonate without any effect on the dehalogenation rate. The maximum dehalogenation rate was $0.13 \mathrm{mmol}$ dichloromethane/h $\cdot 1(2.6 \mathrm{mkat} /$ $\mathrm{kg}$ of protein).
\end{abstract}

Abbreviation: DCM - dichloromethane

\section{Introduction}

Dichloromethane (DCM) is a major industrial solvent which is now found as a major pollutant in groundwater and the atmosphere (Edwards et al. 1982), where half-lives of up to 700 years (aqueous systems) and of 79 days (troposphere), respectively, have been estimated (Baldauf \& Kühn 1985). The compound is a carcinogen (National Toxicology Programm, 1986) and contamination of drinking water resources has to be prevented.
Physico-chemical procedures are often used to remove chlorinated hydrocarbons from industrial waste water and effluent gases, but, however efficient the procedure is, the overall loss of volatile compounds to the atmosphere is generally very high ( $>60 \%$; Ministerium für Ernährung, Landwirtschaft, Umwelt und Forsten; Baden-Württemberg 1983). In contrast, a biological treatment able to degrade DCM at low concentrations has been propagated since the isolation of pseudomonads, hyphomicrobia and other aerobic, facultatively 
methylotrophic bacteria which utilize DCM as their sole source of carbon and energy for growth (Brunner et al. 1980; Stucki et al. 1981; LaPatPolasko et al. 1984; Scholtz et al. 1988).

Biotechnological pilot processes have been designed to remove DCM from industrial waste gases and from process effluents. Gälli \& Leisinger (1985) used an aerobic fluidized-bed reactor to treat model aqueous waste with an efficiency of $>99.9 \%$. An aerobic immersion percolating filter system, in contrast, lost $>80 \%$ DCM to the atmosphere (Winkelbauer \& Kohler 1989). Waste gases have been treated in aerobic trickling-bed reactors and biofilters (Hartmans \& Tramper 1991; Diks \& Ottengraf 1991a, b, c).

Anaerobic treatments of waste DCM are unknown, because no anaerobic cultures utilize the compound as a carbon and energy source, though non-enzymic reductive biotransformations are known (e.g., Egli et al. 1990; Krone et al. 1989a, b). Indeed, the only haloaliphatic compound currently known to serve as a carbon and energy source for anaerobic growth is chloroacetate (Egli et al. 1989). We now report that DCM can be utilized as the sole source of carbon and energy by an anaerobic mixed culture, and that the anaerobic treatment of waste DCM is possible.

\section{Materials and methods}

\section{Materials}

Methane (99.5\% ; Carbagas, Liebefeld-Bern, Switzerland) and chloromethane (99\%; Fluka, Buchs, Switzerland) were from commercial sources. Other chemicals were of reagent grade or better and were obtained from Fluka or from Merck-Schuchardt (München, Germany). The active charcoal was Hydraffin 22E (Lurgi, Frankfurt, Germany) with a porosity of $38 \%$. The groundwater was contaminated by material from paint wastes. The water, which was essentially anoxic $\left(\mathrm{pO}_{2}<1 \%\right)$, contained $8.9 \mathrm{mg} \mathrm{CH}_{2} \mathrm{Cl}_{2} / \mathrm{l}$ and other contaminants which have been documented elsewhere (Winkelbauer \& Kohler 1989).

\section{Analytical methods}

Carbon dioxide and methane (thermal conductivity detector; $5 \AA$ molecular sieve) and hydrogen sulfide (flame photometric detector; activated charcoal) were quantified in Stuttgart after gaschromatographic separation (Fractorap 2350; Carlo Erba, Rodano, Italy). Dissolved organic carbon and total organic carbon were measured in a Tocor 2 analyzer (Mayhak, Hamburg, Germany). Oxygen in the groundwater or the reactor was analyzed in an oxygen electrode (WTW, Weilheim, Germany) with a detection limit of $1 \% \mathrm{O}_{2}$. In Zürich, methane, chloromethane, DCM, toluene, xylene, ethylbenzene and 1,2,4-trimethylbenzene were routinely determined in a flame ionization detector after gas-chromatograph separation on a Porapak P column (Model 8700; Perkin Elmer, Beaconsfield, UK). Tentative identifications were confirmed by co-chromatography with authentic material on other columns (Egli et al. 1987).

Acetate in acidified, cell-free samples was determined in a flame ionization detector after gas-chromatograph separation on a column of $10 \%$ SP1000 with $1 \% \mathrm{H}_{3} \mathrm{PO}_{4}$ on Chromosorb WAW (Supelco, Bellfonte, USA). Formate was analyzed enzymatically (Schaller \& Triebig 1984). Chloride ion in biological samples was determined spectrophotometrically (Bergmann \& Sanik 1957) after oxidation of thiols (Egli et al. 1989). The identification of the chloride ion was confirmed by ion-chromatography with suppressor (AS4A column; Dionex, Sunnyvale, USA). Protein in whole cells was measured by a Lowry-type method (Cook \& Hütter 1981). Biomass in the reactor was estimated from the carbon missing from the mass balance, assuming the formation of $2 \mathrm{~g}$ dry weight/mol $\mathrm{C}$ (Dolfing \& Tiedje 1987)

Volatile components in growth media are considered to be dissolved in the aqueous phase only, with no material in the gas phase. This nomenclature allowed mass balances to be expressed more easily (Egli et al. 1987). Our calculations with the Henry's constant (Grossett 1987) indicated that $\geqslant 97.5 \%$ of DCM was in the aqueous phase. 


\section{Fixed-bed reactor}

The fixed-bed reactor (Fig. 1), near Stuttgart, had a total volume of $43 \mathrm{~m}^{3}$. It contained $30 \mathrm{~m}^{3}$ of activated charcoal and was operated at about $12^{\circ} \mathrm{C}$. These dimensions were chosen to give a sorptive capacity for two months of continuous operation with an assumed input $\left(1.5 \mathrm{~m}^{3} / \mathrm{h}\right)$ of groundwater containing $40 \mathrm{mg} \mathrm{DCM} / \mathrm{l}$. The aqueous input was measured in a rotameter (GEMÜ, Ingelfingen, Germany). The volume of the gas effluent was recorded in a gasmeter (Brandt, Wertheim, Germany).

\section{Sorptive capacity of the active charcoal}

The apparent sorption capacity was defined as a combination of biodegradative activities and sorption processes of the charcoal. The residual apparent sorptive capacity for DCM of the activated charcoal in the reactor was determined in triplicate in the fourth year of operation and compared with freshly reactivated charcoal. Samples of charcoal were taken anaerobically at different depths below the charcoal surface and were transferred immediately to $\mathrm{N}_{2}$-flushed bottles containing an aqueous solution of DCM $(102 \mathrm{mg} / \mathrm{l})$ such that no gas phase remained after closure. DCM in the aqueous phase was monitored for 334 hours. The dry weight of charcoal was measured after the sorptive properties had been examined.

\section{Growth media and enrichment conditions}

Defined minimal salts medium was prepared anaerobically in deionized water and consisted of $50 \mathrm{mM}$ potassium phosphate buffer, $\mathrm{pH} 7.2$, $5.6 \mathrm{mM} \mathrm{NH}_{4} \mathrm{Cl}, 0.4 \mathrm{mM} \mathrm{MgSO}_{4}, 60 \mathrm{mM} \mathrm{NaHCO}_{3}$, $3 \mathrm{mM}$ L-cysteine hydrochloride, $3 \mathrm{mM} \mathrm{Na} 2 \mathrm{~S}$ and $5 \mu \mathrm{M}$ resazurin, which was autoclaved and to which were added aseptically (a) trace elements $(10 \mathrm{ml} / 1$; Balch et al. 1979) which included additionally $0.1 \mathrm{~g} / 1 \mathrm{NiCl}_{2}$ (Schönheit et al. 1979), (b) selenitetungstate solution $\left(1 \mathrm{ml} / 1 ; 5 \mathrm{mMNaOH}, 23 \mu \mathrm{M} \mathrm{Na}_{2}\right.$ $\mathrm{SeO}_{3}, 24 \mu \mathrm{M} \mathrm{Na}_{2} \mathrm{WO}_{4}$ ), and (c) vitamins (stored at $\left.-20^{\circ} \mathrm{C}\right)(10 \mathrm{ml} / \mathrm{l}$; Balch et al. 1979). The salts medium had to be supplemented with either $0.01 \%$ yeast extract or $1 \%$ filter-sterilized, contaminated groundwater, in order to obtain growth in DCMsalts medium with the correct gas phase. The gas phase above the cultures consisted of $\mathrm{N}_{2}$ plus $\mathrm{CO}_{2}$ (80:20) at 2 bar and serum bottles were sealed with Viton stoppers (Egli et al. 1987). DCM was dissolved in salts medium and added to cultures by syringe through the stopper.

The inoculum $(5 \% \mathrm{v} / \mathrm{v})$ for enrichment cultures was biofilm-coated charcoal, which was withdrawn anaerobically from the fixed bed reactor; inocula for subcultures were free of charcoal. All cultures were inoculated in the glovebox, incubated at $30^{\circ} \mathrm{C}$ and shaken once a day. The aqueous and gas phases were sampled at intervals through the septum.

\section{Results}

Mass balances for total carbon and for DCM in the fixed-bed reactor

The fixed-bed reactor, which was used to eliminate DCM from anaerobic groundwater, was conceived as a physical (sorptive) treatment, though methanogenesis indicated the presence of bacteria and methanogens in the reactor (Table 1). After 3 years of continuous operation without any breakthrough of DCM, however, biological degradation of DCM was suspected and mass balances were examined. Typical data (Table 1) showed about $96 \%$ recovery of carbon, which, given the accuracy of measurements (Table 1), indicated negligible losses from the fermenter. Only about $12 \%$ of the total input of carbon was lost from the aqueous phase (Table 1). In contrast, $99.99 \%$ of the DCM was removed in the reactor (Table 1).

Direct confirmation of the degradation of DCM as release of chloride ion was impossible, because the chloride formed (about $0.5 \mathrm{mM}$ ) could not be unambiguously attributed, given 12 to $16 \mathrm{mM}$ chloride ion in the groundwater itself and chloride released in the reactor from other halogenated compounds in the input (Winkelbauer \& Kohler 1991). However, a depth profile of DCM in the active 


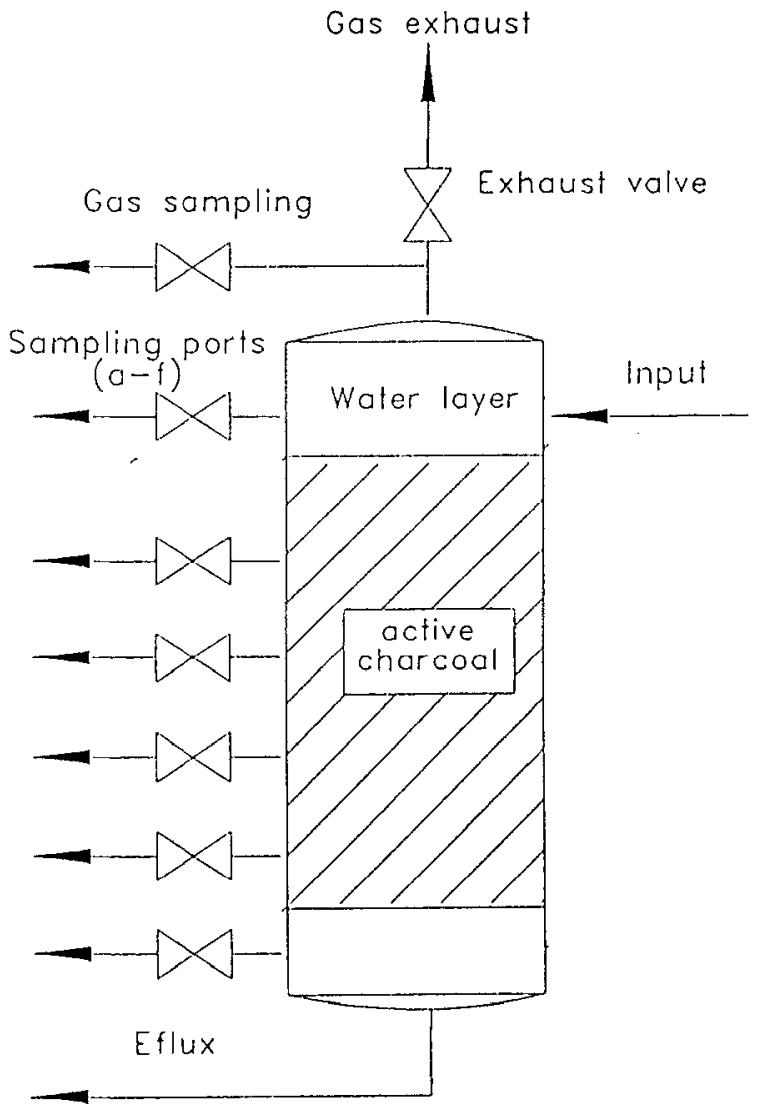

Fig. 1. Diagram of the fixed-bed reactor used to eliminate DCM from contaminated groundwater.

Table 1. Mass balances for total carbon and for DCM in the fixed-bed reactor. ${ }^{a}$

\begin{tabular}{|c|c|c|c|c|}
\hline & \multicolumn{2}{|c|}{ Total carbon } & \multicolumn{2}{|l|}{ DCM } \\
\hline & $\begin{array}{l}\text { Carbon } \\
(\mathrm{g} / \mathrm{h})\end{array}$ & $\begin{array}{l}\% \text { of } \\
\text { total }\end{array}$ & $(\mathrm{g} / \mathrm{h})$ & $\begin{array}{l}\% \text { of } \\
\text { total }\end{array}$ \\
\hline Input & 223 & 100 & 4.1 & 100 \\
\hline Effluent, aqueous & 196 & 88.0 & $<0.0001$ & 0.00 \\
\hline Exhaust gas ${ }^{\mathrm{b}}$ & 16.9 & 7.6 & 0.0043 & 0.01 \\
\hline Biomass & 1.7 & 0.8 & & \\
\hline
\end{tabular}

a The data, from the fourth year of operation, represent the average of a 20 -day sampling period during which the input was $467 \mathrm{l} / \mathrm{h}$ and the gas effluent was $30.3 \mathrm{l} / \mathrm{h}$ : the behaviour was confirmed in a second experiment over 30 days. Inherent errors in the determinations were calculated as $5 \%$ for the input and effluent and $6 \%$ for the exhaust gas. ${ }^{b}$ This gas consisted mainly of methane $(66 \%)$ and $\mathrm{CO}_{2}(16 \%)$ (Winkelbauer \& Kohler 1991). charcoal showed the compound to disappear within the first $0.5 \mathrm{~m}$, the position of the first port under the bed surface (Fig. 1). This indicates a minimum elimination rate of $3.7 \mathrm{mg} \mathrm{DCM} / \mathrm{h} \cdot(\mathrm{kg}$ charcoal $)$ in this section of the reactor.

This elimination rate could not be explained by sorptive processes. The sorptive capacity of fresh charcoal in the groundwater studied was found to be $0.24 \mathrm{~g} \mathrm{DCM} / \mathrm{kg}$. The reactor had already eliminated about $10 \mathrm{~g} \mathrm{DCM} / \mathrm{kg}$ charcoal averaged over the whole reactor, and the apparent sorption capacity was still high $(88 \%, 60 \%$ and $60 \%$ at $0.1 \mathrm{~m}$, $1.0 \mathrm{~m}$ and $2.5 \mathrm{~m}$ below the surface, respectively), compared with fresh charcoal. We thus attributed the elimination of DCM largely to the biological activity of anaerobic microorganisms and we confirmed this in microbiological experiments.

\section{Enrichment cultures to utilize DCM as a carbon and energy source under methanogenic conditions}

We chose methanogenic conditions for enrichment cultures, because the fixed bed reactor was methanogenic. No DCM was transformed in control experiments containing filter-sterilized groundwater. Samples of the biofilm-coated charcoal in unsupplemented $2 \mathrm{mM}$ DCM-salts medium reproducibly caused disappearance of the DCM within 45 days; additional portions of $2 \mathrm{mM}$ DCM disappeared within 5 days. We were initially unable to subculture this activity. However, addition of sterile groundwater or yeast extract overcame the problem. We thus obtained reproducible anaerobic utilization of DCM by the mixed suspended culture in supplemented DCM-salts medium in which the supplement represented $<5 \%$ of the added carbon, and was presumably a growth factor.

When the mixed culture was inoculated into supplemented DCM-salts medium there was a delay followed by slow disappearance of DCM (Fig. 2A); indeed, over the first 13 days, during which the DCM was completely degraded, there was little difference between the turbidity levels and methane formation in the control (groundwater-supplemented salts medium) and in the supplemented DCM-salts medium. Additional portions of DCM, 
however, enabled markedly increased growth (turbidity), compared to the control, and somewhat increased levels of methane.

The low levels of methane led us to question whether the culture was obligately methanogenic, so we added bromoethane sulfonate, an inhibitor of methanogenesis, to the mixed culture (Fig. 2B). Methanogenesis was completely inhibited, but the rates and level of degradation of DCM, as well as growth, were essentially unaffected. Methanogenesis was not necessary for the utilization of DCM.

A comparison of the controls in Figs. 2A and 2B indicates more initial growth and slower initial degradation of DCM in Fig. $2 B$. The difference is in fact independent of the bromoethane sulfonate (not shown) and is caused by constituents of the groundwater, some of which are growth substrates and others of which are inhibitors; the presence of $50 \%(\mathrm{v} / \mathrm{v})$ groundwater resulted in markedly slower growth. Typical components of the groundwater, toluene $(0.2 \mathrm{mM})$, ethylbenzene $(0.2 \mathrm{mM})$, and 1,2,4-trimethylbenzene $(0.2 \mathrm{mM})$ each inhibited the dehalogenation completely. None of the following substances or mixtures had any effect on degradation of DCM: $\mathrm{H}_{2} / \mathrm{CO}_{2}$, formate, formaldehyde, acetate, pyruvate, benzoate, methanol, glucose, succinate, lactose, xylene $(0.2 \mathrm{mM})$ or mixed organic acids (isobutyric acid, valeric acid, isovaleric acid, hexanoic acid).

\section{Mass balance for the utilization of DCM by the mixed culture}

Degradation of DCM by our mixed culture yielded approximately $1.8 \mathrm{~mol} \mathrm{Cl}-/ \mathrm{mol} \mathrm{DCM}$ (Table 2), which confirms extensive degradation of the DCM. The major organic product from DCM was acetate (Table 2), which was identified by co-chromatography on three columns. Smaller amounts of carbon were found in methane and cell material. Trace amounts only of chloromethane were detected $(<1 \mu \mathrm{M})$ and no formate was found. The recovery of carbon was thus $89 \%$. The growth yield was 1.3 to $1.5 \mathrm{~g}$ protein $/ \mathrm{mol} \mathrm{DCM}$. In confirmation of the data in Fig. 2B, cultures in which methanogene-
A

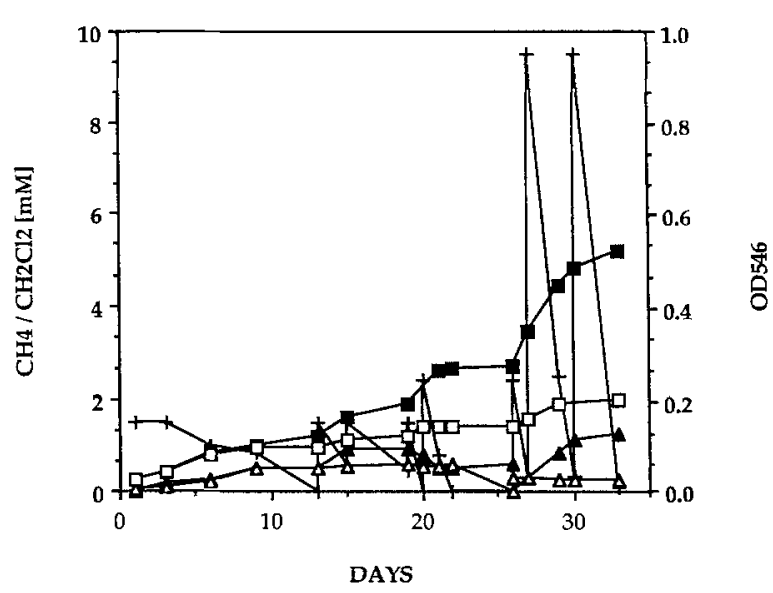

B

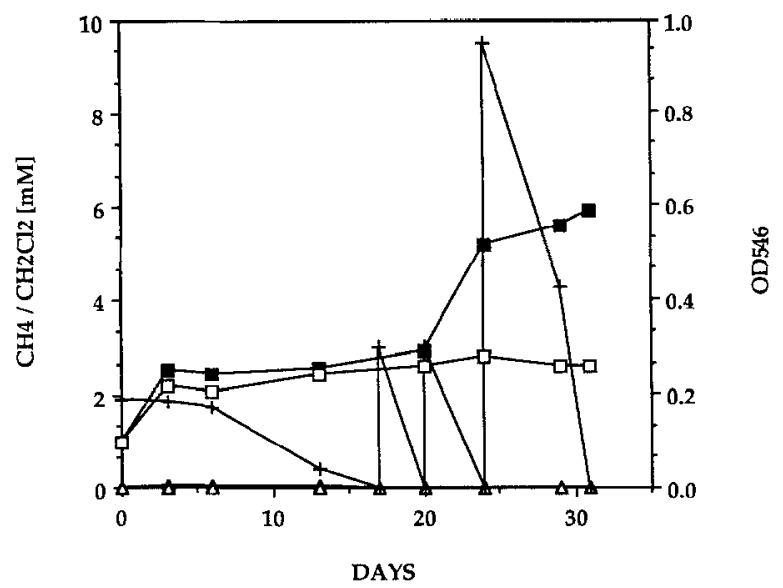

Fig. 2. Growth of anaerobic mixed cultures in DCM-salts medium. DCM was fed to cultures when the previously-supplied DCM was exhausted. The control was a homologous culture without DCM. The growth medium was supplemented with: (A) $1 \%$ groundwater, (B) $10 \%$ groundwater and $50 \mathrm{mM}$ 2-bromoethane sulfonate.,$+ \mathrm{DCM} ; \boldsymbol{\square}, \mathrm{OD}_{546} ; \square, \mathrm{OD}_{546}$ control; $\boldsymbol{\Lambda}, \mathrm{CH}_{4}$; $\triangle, \mathrm{CH}_{4}$ control.

sis was inhibited yielded only traces of methane and increased amounts of acetate (Table 2).

In sterile control experiments, losses of DCM of about $5 \%$ were observed, presumably through the Viton stoppers. We suspect that this loss largely explains the incomplete chloride balance (Table 2) and correspondingly indicates that carbon balances 
would show carbon recoveries $>90 \%$ if corrected for this loss.

The maximum specific rate of utilization of DCM in the mixed culture was $2.6 \mathrm{mkat} / \mathrm{kg}$ protein (Fig. 2A, about day 30).

\section{Discussion}

The fixed-bed reactor, conceived as a sorptive unit for DCM, was obviously functioning largely as a bioreactor to degrade DCM, because the apparent sorptive capacity of the activated charcoal was still high $(>60 \%)$ despite a loading with DCM some 40 -fold in excess of the sorptive capacity. The reactor, as a bioreactor, was over-dimensioned, because DCM was eliminated within the first $11 \%$ $(0.5 \mathrm{~m})$ of the bed height. Aerobic degradation of DCM in this groundwater is known (Kohler et al. $1984)$, but the groundwater $\left(\mathrm{pO}_{2}<1 \%\right)$ contains an amount of oxygen which would not allow significant aerobic growth with the DCM present, and the microflora in the reactor is methanogenic, so the predominant process in the degradation of DCM in the reactor is anaerobic (see also below).
Our anaerobic, microaerotolerant fixed-bed reactor has provided a reliable, long-term decontamination of DCM from contaminated groundwater; other halogenated solvents are also removed from this complex matrix (Winkelbauer \& Kohler 1991). The elimination rate for DCM, $3.7 \mathrm{mg} \mathrm{DCM} / \mathrm{h} \cdot(\mathrm{kg}$ charcoal), is much lower than Gälli \& Leisinger's (1985) aerobic fluidized bed (1.6 $\mathrm{g} \mathrm{DCM} / \mathrm{h} \cdot 1)$ : they were using a salts medium saturated with DCM (as the sole organic component) in a technically complex model system which produced large amounts of biomass (about $12 \mathrm{~g}$ dry weight $/ \mathrm{mol} \mathrm{DCM}$ ) at $30^{\circ} \mathrm{C}$, and they attained an efficiency of $99.9 \%$. The efficiency of our fixed-bed reactor for the removal of DCM from contaminated groundwater (>99.99\%, Table 1) rivals that of Gälli \& Leisinger (1985) and has the advantages that (1) no (pure) oxygen must be pumped into the system, (2) no fluidized bed must be maintained and, (3) very little biomass must be disposed of. We calculate that $45 \mathrm{~kg}$ dry weight of biomass was produced from DCM during three years operation, an amount that did not significantly alter the fluid dynamics of a system with $11 \mathrm{~m}^{3}$ of interstitial space.

Table 2. Disappearance of DCM and formation of products in typical mixed cultures and the effect of 2-bromoethane sulfonate.

\begin{tabular}{lcc}
\hline & Culture without inhibitor & $\begin{array}{c}\text { Culture containing } 50 \mathrm{mM} \\
\text { bromoethane sulfonate }\end{array}$ \\
\hline DCM & Substrate utilized & $11.2 \mathrm{mM}$ \\
& Product formed & $11.0 \mathrm{mM}$ \\
Chloride & $20.5 \mathrm{mM}$ & $21.2 \mathrm{mM}$ \\
Chloromethane & $<1 \mu \mathrm{M}$ & $<1 \mu \mathrm{M}$ \\
Acetate & $3.0 \mathrm{mM}$ & $3.9 \mathrm{mM}$ \\
Methane & $1.4 \mathrm{mM}$ & $0.01 \mathrm{mM}$ \\
Carbon dioxide & $1.4 \mathrm{mM}$ & $0.01 \mathrm{mM}$ \\
Formate & $\mathrm{nd}$ & $\mathrm{nd}$ \\
Protein (or carbon in biomass) & $1.2 \mathrm{mM}$ & $1.4 \mathrm{mM}$ \\
Recovery of carbon & $89 \%$ & $84 \%$
\end{tabular}

Cultures were incubated in triplicate at $30^{\circ} \mathrm{C}$ for 11 days in salts medium supplemented with $0.01 \%$ yeast extract under a gas phase of $\mathrm{N}_{2}$ plus $\mathrm{CO}_{2} ; \mathrm{DCM}$ was added in portions of about 5 to $6 \mathrm{mM}$. These data are corrected for products formed in control cultures incubated in the absence of DCM: in no case was the control value $>15 \%$ of the value given. ${ }^{a}$ nd: not detected. ${ }^{\mathrm{b}}$ Carbon dioxide was not measured, because the background in the medium was high. The values given in this table were calculated from the equations 1 and 2 (in the Discussion) for the formation of methane or acetate from formaldehyde. ${ }^{\mathrm{c}}$ Protein was assayed. Luria (1960) describes protein as $50 \%$ of bacterial dry weight, and carbon also to be $50 \%$ of dry weight. For this mass balance, the protein assayed is onsidered to be equivalent to the amount of carbon in the biomass formed. 
The specific rate of degradation of DCM in the growing anaerobic mixed culture, $2.6 \mathrm{mkat} / \mathrm{kg}$ of protein, is similar to that of pure cultures under aerobic conditions: Hyphomicrobium sp. strain DM2, $2.5 \mathrm{mkat} / \mathrm{kg}$ of protein; strain DM11, $9 \mathrm{mkat} /$ $\mathrm{kg}$ of protein (Scholtz et al. 1988). We thus suspect that improved rates of anaerobic degradation of DCM in wastes can be attained, because Gälli \& Leisinger's (1985) fluidized bed effectively depended on the activity of strain DM2, which has the same specific degradation rate for DCM as our anaerobic mixed culture. On the other hand, growth of the anaerobic mixed culture in DCMsalts medium is subject to inhibition by components in the groundwater. A similar observation has been made for the aerobic degradation of DCM in this groundwater (Schneider et al. 1988). Several known components of the polluted groundwater were examined and found to be toxic, but it is unclear whether the toxic effect is directly on the dechlorinative organism or via another organism in the mixture.

The enrichment cultures for the utilization of DCM were done under methanogenic conditions, because the reactor from which the inocula derived is methanogenic. The enrichment culture was successfully repeated several times till we learned how to subculture the mixed culture which utilized DCM. This culture did contain at least one methanogen, though this organism was not essential for growth, which seemed to be acetogenic (Fig. 2, Table 2). We still do not know the nature of the growth factor required, but the phenomenon resembles the behaviour of the well-known homoacetogen, Acetobacterium woodii (Tschech \& Pfennig 1984). Tschech \& Pfennig (1984) calculated an energy yield of 1.5 to $2 \mathrm{~mol}$ ATP per mol of acetate during homoacetate fermentation of $A$. woodii, and a growth yield, $\mathrm{Y}_{\mathrm{ATP}}$, of up to $4.3 \mathrm{~g}$ (dry weight) in the presence of yeast extract. Our mixed culture displayed a $\mathrm{Y}_{\text {ATP }}$ of 3 to $4 \mathrm{~g}$ (dry weight), assuming homoacetic production of acetate during utilization of DCM.

We feel it important to emphasize that the anaerobic mixed culture grows with a standard yield when utilizing DCM as the sole significant source of carbon and energy, because only a quite different anaerobic fate for DCM, reduction, has been described up till now. The known effect is a biologically-catalyzed, but non-enzymic process which can be observed in autoclaved cells (Egli et al. 1990) but better defined with pure, reduced iron (II) porphyrin, aquacobalamin or coenzyme $F_{430}$ (Klecka \& Gonsior 1984; Krone et al. 1989a,b). Normally, the first reductive step, to chloromethane, is faster than any further reduction to methane (cf. Krone et al. 1989b). We observe negligible accumulation of chloromethane (Table 2) and we assume the reductive process to be of marginal importance in our culture, because effectively no methane was produced in the culture inhibited by bromoethane sulfonate (Table 2), when growth and degradation of DCM were normal. Further, the reductive pathway represents a non-enzymic sink for electrons, not an electron-transport system coupled to energy conservation.

We hypothesize that DCM in the mixed culture is subject to hydrolysis to formaldehyde, analogous to the reaction catalyzed by glutathione S-transferases in aerobic organisms (Ahmed \& Anders 1978; LaRoche \& Leisinger 1990). Formaldehyde is readily metabolized to methane, acetate or $\mathrm{H}_{2} / \mathrm{CO}_{2}$ in different anaerobic microorganisms (Ljungdahl 1983; Fuchs 1986):

$$
\begin{aligned}
& 2 \mathrm{CH}_{2} \mathrm{O}+\mathrm{H}_{2} \mathrm{O} \rightarrow \mathrm{HCO}_{3}^{-}+\mathrm{CH}_{4}+\mathrm{H}^{+} \\
& \Delta \mathrm{G}^{\circ \prime}=-89.6 \mathrm{~kJ} / \mathrm{mol} \mathrm{CH}_{2} \mathrm{O} \\
& 2 \mathrm{CH}_{2} \mathrm{O} \rightarrow \mathrm{CH}_{3} \mathrm{COO}^{-}+\mathrm{H}^{+} \\
& \Delta \mathrm{G}^{\prime \prime}=-74.2 \mathrm{~kJ} / \mathrm{mol} \mathrm{CH}_{2} \mathrm{O} \\
& \mathrm{CH}_{2} \mathrm{O}+\mathrm{H}_{2} \mathrm{O} \rightarrow \mathrm{HCO}_{3}^{-}+2 \mathrm{H}_{2}+\mathrm{H}^{+} \\
& \Delta \mathrm{G}^{\prime \prime}=-21.8 \mathrm{~kJ} / \mathrm{mol} \mathrm{CH}_{2} \mathrm{O}
\end{aligned}
$$

The Gibb's free energies, calculated from Thauer et al. (1977), indicate that all three reactions are thermodynamically favourable. We presume that we have either a homoacetogenic bacterium which utilizes DCM or a hydrogen-producing fermentative bacterium in co-culture with methanogens and acetogens as hydrogen-consuming syntrophic partners. Should a fermentative organism be involved, the $\Delta \mathrm{G}^{\circ}$-value indicates that growth in pure culture is thermodynamically feasible. 


\section{Acknowledgements}

We are grateful to Dr. A. Meier, EAWAG, for doing the ion-chromatographic analyses. The work in Zürich was supported by a grant of the Swiss Federal Institute of Technology, Zürich.

\section{References}

Ahmed EA \& Anders MW (1978) Metabolism of dihalomethanes to formaldehyde and inorganic halide II. Biochem. Pharmacol. 27: 2021-2025

Balch WE, Fox GE, Magrum LJ, Woese CR \& Wolfe RS (1979) Methanogens: reevaluation of a unique biological group. Microbiol. Rev. 43: 260-296

Baldauf G \& Kühn W (1985) Halogenorganische Verbindungen im Grundwasser: Vorkommen, Verbreitung und Aufbereitung. Neue Deliwa-Z. 4: 121-131

Bergmann JG \& Sanik J (1957) Determination of trace amounts of chlorine in naphtha. Anal. Chem. 29: 241-243

Brunner W, Staub D \& Leisinger T (1980) Bacterial degradation of dichloromethane. Appl. Environ. Microbiol. 17: 1245-1267

Cook AM \& Hütter R (1981) s-Triazines as nitrogen sources for bacteria. J. Agric. Food Chem. 29: 1135-1143

Diks RM \& Ottengraf SP (1991a) Verification studies of a simplified model for the removal of dichloromethane from waste gases using a biological trickling filter (part I). Bioprocess. Eng. 6: 93-99

- (1991b) Verification studies of a simplified model for the removal of dichloromethane from waste gases using a biological trickling filter (part II). Bioprocess. Eng. 6: 131-140

- (1991c) Process engineering aspects of biological waste gas purification. In: Verachtert H \& Verstraete W (Eds) Environmental Biotechnology, Vol 1 (pp 353-367). Koninklijke Vlaamse Ingenieursvereniging, Brussels

Dolfing J \& Tiedje JM (1987) Growth yield increase linked to reductive dechlorination in a defined 3-chlorobenzoate degrading methanogenic coculture. Arch. Microbiol. 149: 102105

Edwards PR, Campbell I \& Milne GS (1982) The impact of chloromethanes on the environment. Chem. Ind. 41: 619-622

Egli C, Scholtz R, Cook AM \& Leisinger T (1987) Anaerobic dechlorination of tetrachloromethane and 1,2-dichloromethane to degradable products by pure cultures of Desulfobacterium sp. and Methanobacterium sp. FEMS Microbiol. Lett. 43: 257-261

Egli C, Stromeyer S, Cook AM \& Leisinger T (1990) Transformation of tetra- and trichloromethane to $\mathrm{CO}_{2}$ by anaerobic bacteria is a non-enzymatic process. FEMS Microbiol. Lett. 68: 207-212

Egli C, Thüer M, Suter D, Cook AM \& Leisinger T (1989) Monochloro- and dichloroacetic acids as carbon and energy sources for a stable, methanogenic mixed culture. Archiv. Microbiol. 152: 218-223

Fuchs $\mathrm{G}$ (1986) $\mathrm{CO}_{2}$ fixation in acetogenic bacteria: variations on a theme. FEMS Microbiol. Rev. 39: 181-213

Gälli R \& Leisinger T (1985) Specialized bacterial strains for the removal of dichloromethane from industrial waste. Conserv. Recycl. 8: 91-100

Gossett JM (1987) Measurement of Henry's Law constants for $\mathrm{C}_{1}$ and $\mathrm{C}_{2}$ chlorinated hydrocarbons. Environ. Sci. Technol. 21: $202-208$

Hartmans S \& Tramper J (1991) Dichloromethane removal from waste gases with a trickle-bed bioreactor. Bioprocess. Eng. 6: 83-92

Klecka GM \& Gonsior SJ (1984) Reductive dechlorination of chlorinated methanes and ethanes by reduced iron (II) porphyrines. Chemosphere 13: 391-402

Kohler H, Scholz-Muramatsu H \& Bradtke D (1986) Biologische Elimination von Dichlormethan in Gegenwart leicht abbaubarer Kohlenwasserstoffe. GWF Gas Wasserfach: Wasser/Abwasser 127: 437-441

Krone UE, Laufer K, Thauer RK \& Hogenkamp HCP (1989a) Coenzyme $\mathrm{F}_{430}$ as a possible catalyst for the reductive dehalogenation of chlorinated $\mathrm{C}_{1}$-hydrocarbons in methanogenic bacteria. Biochemistry 28: 10061-10065

Krone UE, Thauer RK \& Hogenkamp HCP (1989b) Reductive dehalogenation of chlorinated $\mathrm{C}_{1}$-hydrocarbons mediated by corrinoids. Biochemistry 28: 4908-4914

La Roche SD \& Leisinger T (1990) Sequence analysis and expression of the bacterial dichloromethane dehalogenase structural gene, a member of the glutathione S-transferase supergene family. J. Bacteriol. 172: 164-171

LaPat-Polasko LT, McCarty PL \& Zehnder AJB (1984) Secondary substrate utilization of methylene chloride by an isolated strain of Pseudomonas sp. Appl. Environ. Microbiol. 47: $825-830$

Ljungdahl LG (1983) Formation of acetate using homoacetate fermenting anaerobic bacteria. In: Wise DL (Ed) Organic Chemicals from Biomass (pp 219-248). Benjamin/Cummings, London

Luria SE (1960) The bacterial protoplasm: composition and organization. In: Gunsalus IC \& Stainer RY (Eds) The Bacteria, Vol 1 (pp 1-34). Academic Press, New York

Ministerium für Ernährung, Landwirtschaft, Umwelt und Forsten; Baden-Württemburg (1983) Leitfaden für die Beurteilung und Behandlung von Grundwasservereinungen durch leichtflüchtige Chlorkohlenwasserstoffe. Landesanstalt für Umweltschutz, Karlsruhe

National Toxicology Programm (1986) Toxicology and carcinogenesis studies of dichloromethane in F344/M rats in B6C3FL mice. NTPTR 306. NIH Pub., No 86-256 L. US Dept. Health of Human Services

Schaller KH \& Tricbig G (1984) Formate determination with formate dehydrogenase. In: Bergmeyer KH (Ed) Methods of Enzymatic Analysis, 3rd edition (pp 688-672). Verlag Chemie, Deerefield Beach

Schneider V, Scholz-Muramatsu H \& Geiser S (1988) Hem- 
mung der biologischen Elimination von Dichlormethan durch kontaminiertes Grundwasser. GWF Gas Wasserfach: Wasser/Abwasser 129: 755-758

Scholtz R, Wackett LP, Egli C, Cook AM \& Leisinger T (1988) Dichloromethane dehalogenase with improved catalytic activity isolated from a fast-growing dichloromethane-utilizing bacterium. J. Bacteriol. 170: 5698-5704

Schönheit P, Moll J \& Thauer RK (1979) Nickel, cobalt and molybdenum requirements for growth of Methanobacterium thermoautotrophicum. Arch. Microbiol. 123: 105-107

Stucki G, Gälli R, Ebersold HR \& Leisinger T (1981) Dehalogenation of dichloromethane by cell extracts of Hyphomicrobium DM2. Arch. Microbiol. 130: 366-371
Thauer RK, Jungermann K \& Decker K (1977) Energy conservation in chemotrophic anaerobic bacteria. Bacteriol. Rev. 41: $100-180$

Tschech A \& Pfennig N (1984) Growth yield increase linked to caffeate reduction in Acetobacterium woodii. Arch. Microbiol. 137: 163-167

Winkelbauer W \& Kohler H (1989) Biologischer Abbau von leichtflüchtigen Chlorkohlenwasserstoffen in offenen Systemen am Beispiel von Dichlormethan in einem Tauchtropfkörper. GWF Gas Wasserfach: Wasser/Abwasser 130: 13-20 - (1991) Biologischer Abbau von Dichlormethan unter anaeroben Bedingungen in einer Aktivkohleanlage. GWF Gas Wasserfach: Wasser/Abwasser 132: 425-432 